\title{
Mô hình chính quyền bang tại Hoa Kỳ và một số kiến nghị đối với tổ chức nhà nước việt nam
}

\author{
Phạm Quang Huy ${ }^{1, *}$, Phạm Ngọc Lam Giang ${ }^{2}$ \\ ${ }^{1} V u$ Pháp chế, Bộ Tài chính \\ ${ }^{2}$ Viện Nghiên cứu Châu Mỹ, Viện Hàn lâm KHXH Việt Nam \\ Nhận ngày 25 tháng 10 năm 2017 \\ Chỉnh sửa ngày 23 tháng 11 năm 2017; Chấp nhận đăng ngày 28 tháng 12 năm 2017
}

\begin{abstract}
Tóm tắt: Bài viết phân tích mối quan hệ giữa chính quyền liên bang và chính quyền bang Hoa Kỳ, phân cấp và tự trị của chính quyền bang. Các tác giả đề xuất một số kiến nghị liên quan đến phân cấp tổ chức nhà nước tại Việt Nam.
\end{abstract}

Tù khoá: Tổ chức nhà nước, chính quyền Hoa Kỳ, chính quyền bang.

\section{Mối quan hệ giữa chính quyền liên bang và chính quyền tiểu bang Hoa Kỳ}

[Trong phạm vi bài viết này, đối với chính quyền Hoa Kỳ, khái niệm "chính quyền trung ương" có thể được hiểu là "chính quyền liên bang", và "chính quyền địa phương" có thể được hiểu là chính quyền các tiểu bang.]

Nhà nước Hoa Kỳ được tổ chức theo hình thức cấu trúc liên bang do các bang độc lập có chủ quyền hợp thành. Việc xác định mối quan hệ giữa cơ quan nhà nước trung ương và địa phương là việc xác định thẩm quyền giữa các cơ quan đó với nhau, các thẩm quyền này thể hiện sự tác động giữa các cơ quan nhà nước trung ương với địa phương và ngược lại.

Theo Học thuyết phân quyền của Montesquieu, nhà nước liên bang được tổ chức theo nguyên tắc phân quyền dọc từ trung ương đến địa phương. Việc tổ chức nhà nước của các

\footnotetext{
* Tác giả liên hệ. ĐT.: 84-24-2220 2828 - Máy lẻ. 6007

Email: phamquanghuy@mof.gov.vn.

https://doi.org/10.25073/2588-1167/vnuls.4122
}

nước liên bang trước hết phải có sự phân biệt thẩm quyền giữa liên bang và các bang. Trong việc tổ chức nhà nước liên bang, vấn đề quan trọng là phân chia quyền lực giữa liên bang với các bang. Việc phân chia quyền lực nhà nước theo chiều dọc giữa liên bang và các bang diễn ra theo 3 hình thức sau: i) Những thẩm quyền đặc biệt chỉ có ở liên bang; ii) Những thẩm quyền đặc biệt của các bang; iii) Những thẩm quyền chung của liên bang và các bang. Chính quyền Hoa Kỳ theo hệ thống liên bang (federalism) trong đó chính quyền trung ương (liên bang) tồn tại song song với chính quyền địa phương (tiểu bang). Mọi hành động của chính quyền liên bang phải được Hiến pháp cho phép. Ngoài ra, Hiến pháp cũng có quy định một số lĩnh vực mà cả hai chính quyền đều có thẩm quyền, nhưng thẩm quyền của chính quyền liên bang được ưu tiên hơn. Trong tổ chức chính quyền Hoa Kỳ, sự phân biệt quyền lực giữa liên bang và tiểu bang được quy định cụ thể trong hiến pháp liên bang. 


\subsection{Mối quan hệ giũa hiến pháp liên bang và hiến pháp bang}

Chính quyền bang tồn tại và vận hành song song với chính quyền liên bang kể từ khi lập quốc. Các nhà lập quốc cho rằng chính quyền sẽ hoạt động hiệu quả hơn bởi một nền chính phủ chung hơn là một nhóm các nền chính phủ riêng lẻ. Từ kinh nghiệm đúc kết, ví dụ việc trao đổi buôn bán thương mại với nước ngoài và giữa các tiểu bang với nhau nên được quy định bởi một nhà cầm quyền duy nhất, tiến hành cho toàn thể quốc gia; chỉ cách này mới có thể được đảm bảo tính đồng nhất, và sự đồng nhất trong những vấn đề như thế này là điều vô cùng cần thiết cho nền hòa bình và sự trường tồn vĩnh viễn của liên minh. Do đó, chính quyền liên bang đã được trao quyền hành để đảm bảo tính thống nhất này và những vấn đề khác, và những quyền hành còn lại sẽ được để lại cho các tiểu bang, đúng với chiến lược của các bang. Vì vậy, điều này nảy sinh một vấn đề là chính quyền liên bang được ủy quyền cho các quyền hạn được liệt kê hoặc ủy nhiệm, trong khi các tiểu bang có những quyền hạn trong phạm vi lãnh thổ của mình miễn không bị ngăn cấm bởi thỏa thuận chung.

Hiến pháp liên bang và hiến pháp bang là hai văn kiện có mối quan hệ mật thiết, đưa ra khung pháp lý toàn diện cho chính quyền Hoa Kỳ. Trong quá trình xác lập hệ thống chính quyền, Hiến pháp Hoa Kỳ đã hoàn thành ba nhiệm vụ: (i) Hiến pháp đã thiết lập nên cấu trúc chính quyền gồm ba nhánh: lập pháp, hành pháp và tư pháp trong một chế độ liên bang. (ii) Hiến pháp đã phân bổ một số quyền lực cho chính quyền liên bang. (iii) Hiến pháp đã kiềm chế chính phủ trong việc thực hiện các quyền lực này, đảm bảo cho một số quyền cá nhân vẫn được tôn trọng [1]. Như vậy, Hiến pháp đã trao và đặt ra những giới hạn quyền lực cho chính quyền liên bang. Trước khi Hiến pháp Hoa Kỳ được lập nên, các bang đã lập nên chính quyền của riêng mình và có hiến pháp riêng. Trong việc tuân theo Hiến pháp Hoa Kỳ, các bang chia sẻ một số quyền lực của mình cho chính quyền liên bang và chuyển giao một số chủ quyền.
Tuy nhiên các bang vẫn giữ lại một số quyền lực liên quan đến dân sự. Không giống như quyền lực đã được quy định cho chính quyền liên bang, những quyền hành giao cho các tiểu bang không thể liệt kê được. Các quyền hành này đa dạng về đặc điểm, và rất rộng đến mức mà nỗ lực để liệt kê sẽ phải bao gồm việc biên mục ra vô số những mối quan hệ xã hội và kinh doanh trong cuộc sống. Những quyền hạn của chính quyền liên bang có vẻ lớn hơn rất nhiều khi so sánh với quyền hạn của các tiểu bang, một phần các quyền hành này được quy định trong hiến pháp và một phần vì phạm vi áp dụng các quyền hành này nằm trong toàn bộ phạm vi quốc gia. Tuy nhiên trong thực tế, các quyền hạn từ chính quyền liên bang ít hơn và tầm ảnh hưởng yếu hơn so với quyền hạn từ các bang tới số đông quần chúng nhân dân. Quyền hạn của các tiểu bang bao gồm những vấn đề như quy định về quyền sở hữu, quyền sử dụng, và phân chia tài sản, tiến hành kinh doanh và công nghiệp, thực hiện và thi hành các bản hợp đồng, vấn đề tồn giáo tín ngưỡng, giáo dục, hôn nhân, li hôn và những mối quan hệ nội bộ nói chung; các cuộc bỏ phiếu và bầu cử, sự thi hành bộ luật hình sự. Trong sự phân chia quyền lực chính quyền liên bang và chính quyền các tiểu bang, tiểu bang đã giành được quyền hạn nhiều nhất và liên bang đã giành được quyền hạn cao nhất và vì vậy sự cân bằng giữa cả hai phía được bảo đảm.

Trong khi Hiến pháp Hoa Kỳ là bản hiến pháp đại thể, mang tính quy định khung và tính ổn định cao (ít sửa đổi) thì hiến pháp các bang bao gồm các quy định cụ thể, rõ ràng về phạm vi thẩm quyền của từng bang. Vì hiến pháp bang điều chỉnh các mối quan hệ trong phạm vi tiểu bang nên nhu cầu sửa đổi thường xuyên hơn, quy trình sửa đổi dễ dàng hơn. Hiến pháp Hoa Kỳ phải trải qua một quy trình phức tạp và phải được sự đồng thuận của các cơ quan lập pháp ở hai phần ba các bang.

\subsection{Nhũng thẩm quyền thuộc về liên bang}

\subsection{1. Đặc điểm về thẩm quyền của liên bang}

Những thẩm quyền thuộc về chính quyền liên bang Hoa Kỳ có các đặc điểm sau: 
Thư nhất, Chính quyền liên bang được nhân dân Hoa Kỳ (thông qua Hiến pháp) trao quyền để hoạt động và thực thi nhiệm vụ của mình. Tuy nhiên các quyền này là có giới hạn và mọi hành động của chính quyền liên bang phải được Hiến pháp cho phép. Các nhà lập quốc và hội nghị Hiến pháp đã nhất trí chỉ giao cho chính quyền liên bang một số quyền có giới hạn và số lượng rõ ràng. Điều này có nghĩa là chính quyền liên bang (hành pháp liên bang, lập pháp liên bang và tòa án liên bang) chỉ có quyền hạn được quy định cụ thể trong Hiến pháp Hoa Kỳ.

Thư hai, Hiến pháp quy định rõ chính quyền liên bang cụ thể là Quốc hội Hoa Kỳ được phép ban hành tất cả các luật "cần thiết và thích hợp" để thi hành các quyền mà Hiến pháp giao cho chính quyền liên bang (khoản 18 Điều I Hiến pháp Hoa Kỳ). Điều này có nghĩa là nếu Quốc hội Hoa Kỳ muốn thiết lập một tiêu chí nào đó trong quyền hạn được Hiến pháp cho phép thì Quốc hội Hoa Kỳ có thể dùng các phương thức khác nhau, tuy nhiên các phương thức đó phải tuân thủ 2 điều kiện: (1) liên quan một cách hợp lý đến tiêu chí đó, và (2) phương thức sử dụng không bị Hiến pháp cấm [2].

Thú $b a$, mọi hành vi của chính quyền liên bang (dù trong thẩm quyền) không được xâm phạm quyền và lợi ích cụ thể của công dân đã được Hiến pháp bảo vệ. Hành vi của chính quyền liên bang mặc dù được Hiến pháp cho phép cũng sẽ bị xem là vi hiến nếu hành vi đó vi phạm điều khoản Hiến pháp khác đảm bảo quyền lợi của công dân.

Thư tu, trong một số lĩnh vực, khi thẩm quyền của liên bang có xung đột với chính quyền bang thì thẩm quyền của chính quyền liên bang được ưu tiên hơn theo quy định của Hiến pháp Hoa Kỳ.

\subsubsection{Những thẩm quyền thuộc về chinh} quyền liên bang

a) Quyền lực Hiến pháp trao cho hệ thống tam quyền phân lập liên bang:

Hệ thống tam quyền phân lập liên bang gồm ba nhánh: lập pháp, hành pháp và tư pháp. Tương đương với mỗi nhánh, quyền lực nhà nước lần lượt được trao cho Quốc hội Hoa Kỳ, Tổng thống Hoa Kỳ và Tòa án liên bang Hoa Kỳ.

Quốc hội Hoa Kỳ có những quyền hạn hiến định như sau: Quyền (ban hành luật để) quản lý thương mại liên bang (tức là mọi giao dịch có phạm vi từ hai bang trở lên) và quản lý ngoại thương; Quyền thu thuế và chi (tiền thuế thu được); Quyền quản lý Thủ Đô (District of Columbia); Quyền quản lý đất đai thuộc sở hữu chính quyền liên bang; Quyền tuyên chiến và quyền thành lập quân đội và cấp ngân sách cho quân đội [3].

Tổng thống Hoa Kỳ có những quyền hiến định như sau: Thi hành luật do Quốc hội ban hành; Lãnh đạo và điều khiển quân đội với chức vụ Tổng Tư lệnh; Ký kết các hiệp ước với nước ngoài với sự phê chuẩn của Thượng viện; Bổ nhiệm Đại sứ Mỹ, và có quyền ngầm định về kiểm soát chính sách ngoại giao; Bổ nhiệm các chức vụ trong bộ máy liên bang bao gồm: các chức vụ trong nội các, các thẩm phán và các đại sứ; Ân xá các tội phạm luật liên bang trước khi bị tòa kết án; Phủ quyết các đạo luật Quốc hội ban hành [4].

Quyền lực Hiến pháp giao cho Tòa án: Xem xét tính hợp hiến của luật do Quốc hội ban hành; Xem xét các phán quyết của tòa án của tiểu bang nếu các phán quyết ấy dựa trên luật liên bang; Thực thi quyền lực Tòa án do Hiến pháp phân công; Tòa án Liên Bang có quyền quyết định các vụ án trong đó: có vấn đề liên quan đến Hiến pháp, có vấn đề liên quan đến luật liên bang, liên quan đến biển đảo, có bất đồng giữa chính quyền của 2 tiểu bang trở lên, có bất đồng giữa các công dân của những tiểu bang khác nhau, giữa cá nhân hoặc chính quyền tiểu bang với cá nhân hoặc chính quyền nước ngoài [5].

b) Các quyền cụ thể khác của chính quyền liên bang

- Quyền quản lý thương mại

Quyền lực quan trọng nhất mà Hiến pháp trao cho Quốc hội liên bang là quyền "quy định thương mại với ngoại quốc, giữa các tiểu bang và các bộ lạc da đỏ". Các cơ quan Hành pháp do Tổng thống đứng đầu thực hiện quản lý 
thương mại theo các luật do Quốc hội ban hành. Theo giải thích của Hiến pháp Hoa Kỳ: Thương mại không chỉ là buôn bán mà còn là tất cả các dạng hoạt động thương mại khác; "Thương mại giữa các bang" - thương mại liên bang không chỉ là các giao dịch qua ranh giới giữa các bang mà còn là bất cứ hoạt động nào ảnh hưởng đến thương mại của hơn một bang; Quyền quản lý thương mại là quyền khuyến khích, xúc tiến, cấm hoặc hạn chế thương mại [6].

Các lĩnh vực thương mại thuộc thẩm quyền quản lý của chính quyền liên bang bao gồm: Vận tải thương mại; Phương tiện thương mại; Vật chất, thông tin thương mại và Các hoạt động có "ảnh hưởng đáng kể” đến thương mại. Ngoài ra, những hoạt động, hành vi cụ thể nếu có mối liên hệ trực tiếp đến thương mại đều có thể thuộc thẩm quyền thương mại của Quốc hội [7].

- Quyền đúc và in tiền cùng với các quy định cho phép Quốc hội quản lý thương mại và vay tiền, Quốc hội đã có quyền thành lập các ngân hàng quốc gia và thiêt lập Hệ thống Dự trữ Liên bang.

\section{- Quyền đánh thuế}

Quốc hội Hoa Kỳ có thẩm quyền "đặt ra và thu các khoản thuế”. Đây là một nguồn quyền lực độc lập của Quốc hội liên bang, tương tự như quyền "quản lý thương mại liên bang" được quy định trong Điều khoản Thương mại của Hiến pháp. Quốc hội sử dụng quyền đánh thuế bằng cách ban hành các luật quản lý thuế. Các luật này quản lý các hành vi qua hình thức các loại thuế và tạo ra nguồn thu từ thuế liên quan đến các hành vi này.

Hiến pháp Hoa Kỳ cũng đặt ra một số giới hạn cho quyền đánh thuế của Quốc hội liên bang, đó là:

+ Thuế hải quan và thuế đánh lên hoạt động thương mại phải đồng nhất, các loại thuế này không thể có sự phân biệt hay ưu đãi riêng cho bất cứ địa phương nào.

+ Miễn thuế xuất khẩu: mọi hoạt động xuất khẩu của mọi địa phương ra nước ngoài điều được miễn thuế xuất khẩu đánh lên hàng hóa, dịch vụ xuất khẩu.

\section{- Quyền chi tiêu}

Quốc hội Hoa Kỳ có thẩm quyền thu thuế nhằm mục đích "trả nợ và trang trải quốc phòng cùng các khoản chi phí phúc lợi của Hiệp Chủng Quốc". Đây là một quy định rõ ràng cụ thể về "quyền chi tiêu". Đây cũng là một loại quyền lực độc lập, giống như quyền quản lý thương mại liên bang. Quốc hội liên bang có thể đặt ra các khoản chi tiêu để đạt được những ích lợi ở mọi cấp độ từ trung ương đến địa phương, cho dù những ích lợi ấy vượt ngoài thẩm quyền của các quyền lực độc lập khác [8]. Quốc hội có quyền đặt ra các điều kiện khi sử dụng quyền chi tiêu của mình để áp đặt các đối tượng thụ hưởng phải có những hành vi thích hợp. Những điều kiện này có thể nhằm mục đích quản lý những hành vi liên đới khác. Ví dụ: Quốc hội có thể lập ra quỹ bảo trì đường cao tốc và áp đặt điều kiện về kết cấu đường bộ, giới hạn tốc độ.v.v. cho các địa phương nào muốn nhận tài trợ từ quỹ này, với mục đích "liên đới" là nhằm quản lý thống nhất các tiêu chuẩn xây dựng phát triển vận hành đường cao tốc trên toàn quốc. Những quy định này cũng nhằm khắc phục tình trạng không tuân thủ các quy định bắt buộc nhưng vẫn được hưởng lợi vì thiếu các điều kiện ràng buộc. Sở dĩ Quốc hội có thể đặt ra các điều kiện này là vì Hiến pháp có quy định cho Quốc hội được phép sử dụng mọi biện pháp cần thiết để đạt được các mục tiêu nằm trong thẩm quyền quản lý của mình.

\section{- Quyền tuyên chiến:}

Quốc hội liên bang được Hiến pháp giao cho quyền tuyên chiến và để phục vụ mục đích này, Quốc hội cũng được giao cho quyền thu thuế để trang trải quốc phòng. Ngoài ra Quốc hội còn được trao quyền xây dựng và duy trì quân đội cũng như hải quân. Thẩm quyền về chiến tranh của Quốc hội cũng được mở rộng sang quản lý những lĩnh vực "hậu chiến" khi giao tranh đã kết thúc nhưng các yếu tố có liên quan đến chiến tranh trước đó vẫn còn tồn tại kéo dài.

- Quyền ký kết các điều ước quốc tế:

Tổng thống có quyền ký kết hiệp ước với nước ngoài theo sự phê chuẩn của Quốc hội. 
Những hiệp ước quốc tế đã được phê chuẩn nếu có mâu thuẫn với các luật liên bang trước đó thì các hiệp ước quốc tế có hiệu lực cao hơn. Tuy nhiên, không một hiệp ước nào có thể xâm phạm các quyền đã được Hiến pháp bảo hộ hoặc cấm đoán. Tổng thống có thể ký kết "thỏa thuận hành pháp" với nước ngoài mà không thông qua Quốc hội, với điều kiện các vấn đề thỏa thuận nằm trong phạm vi thẩm quyền của Tổng thống. Các "thỏa thuận hành pháp" sau khi ký kết cũng có giá trị như hiệp ước, nhưng không được trái với luật hiện hành.

Quyền ký kết các điều ước quốc tế của Quốc hội Hoa Kỳ được củng cố thêm ở khoản 10 Điều I Hiến pháp Hoa Kỳ bằng các quy định về các quyền không cho phép đối với các bang. Theo các điều khoản này, chỉ có chính quyền liên bang có quyền lập hiệp ước hoặc đàm phán với các quốc gia nước ngoài.

- Quyền quản lý ngoại giao: theo "nguyên tắc hiến pháp" được giải thích bởi Tòa án tối cao liên bang, quyền quản lý ngoại giao thuộc về Quốc hội và Tồng thống mà không thuộc về địa phương.

- Quyền quản lý lãnh thổ:

Ngoài những quyền cụ thể được liệt kê ở trên, chính quyền liên bang còn có thẩm quyền riêng biệt đối với lãnh thổ Hoa Kỳ. Khoản 3 Điều VI Hiến pháp Hoa Kỳ trao cho Quốc hội quyền hoạch định và xây dựng các luật lệ và quy chế cần thiết liên quan tới lãnh thổ hoặc sở hữu khác thuộc về Hoa Kỳ. Quyền lực của Quốc hội Hoa Kỳ đối với các đơn vị hành chính cấp lãnh thổ mà không thuộc bất cứ 1 tiểu bang nào, là độc quyền và nhất quán. Những khu vực lãnh thổ thuộc thẩm quyền điều hành chính quyền liên bang bao gồm: Đặc khu liên bang của Hoa Kỳ, Những khu dành riêng cho người bản thổ Mỹ, Những khu dành riêng cho người bản thổ Mỹ (American Indian reservation), Các lãnh thổ của Hoa Kỳ, Những vùng quốc hải của Hoa Kỳ, Các quốc gia liên kết tự do [9].

Bên cạnh Quốc hội, Bộ Nội vụ Hoa Kỳ là một trong những cơ quan thuộc chính quyền liên bang chịu trách nhiệm các vấn đề nội bộ về "lãnh thổ Hoa Kỳ". Bộ Nội vụ được thành lập theo một đạo luật được thông qua ngày 03/03/1849 trong kỳ họp Quốc hội lần thứ 30 . Bộ Nội vụ có một phạm vi rộng gồm nhiều trách nhiệm. Phạm vi này bao gồm việc điều hợp các chính quyền lãnh thổ, các trách nhiệm cơ bản về đất công, và vô số các nhiệm vụ khác nữa. Đối ngược lại các bộ nội vụ có tên tương tự tại nhiều quốc gia khác trên thế giới, Bộ Nội vụ Hoa Kỳ không nhận trách nhiệm đối với các chính quyền địa phương hay điều hành công chính. Trừ trường hợp đối với các khu dành riêng cho người bản thổ Mỹ qua Cục Đặc trách người bản thổ Mỹ (Bureau of Indian Affairs), và các thuộc địa hải đảo qua Phòng Quốc hải vụ (Office of Insular Affairs) [10].

\subsubsection{Nghĩa vu của chính quyền liên bang đối} với các bang

Ngoài việc quy định những quyền riêng biệt của chính quyền liên bang, Hiến pháp Hoa Kỳ cũng quy định nghĩa vụ của chính quyền liên bang đối với các bang tại khoản 4 Điều IV, đó là: "Hoa Kỳ sẽ đảm bảo cho mỗi bang trong liên bang này một thể chế chính quyền cộng hòa; và sẽ bảo vệ mỗi bang chống lại sự xâm lược; và theo yêu cầu của cơ quan lập pháp hoặc hành pháp (khi cơ quan lập pháp không thể nhóm họp) để chống lại tình trạng bạo lực trong nước". Phần này yêu cầu chính quyền liên bang đảm bảo rằng mọi bang đều có "tổ chức chính quyền cộng hòa”. Một chính quyền cộng hòa là một chính quyền trong đó nhân dân bầu ra các đại diện để quản lý bang. Tòa án Tối cao quy định rằng Quốc hội, chứ không phải các tòa án, phải quyết định xem một chính quyền bang có tính chất cộng hòa hay không. Nếu Quốc hội chấp nhận các Thượng nghị sỹ và Hạ nghị sỹ của một bang thì hành động đó biểu thị rằng Quốc hội cho rằng chính quyền bang đó là cộng hòa. Cơ quan lập pháp hoặc thống đốc của một bang có thể yêu cầu sự trợ giúp của liên bang trong việc giải quyết các cuộc nổi loạn hay các dạng tội ác nội bộ khác. Tuy nhiên Tổng thống không cần sự chấp thuận của một bang trong việc gửi các lực lượng liên bang, bao gồm cả các lực lượng quân đội để thực hiện các đạo luật liên bang. Trong cuộc bãi công Pullman 
năm 1894, chính quyền liên bang đã gửi các sư đoàn tới Inllinois mặc dù thống đốc bang không muốn. Năm 1957 Tổng thống Eisenhower đã quốc hữu hóa Lực lượng Phòng vệ bang Arkansas nhằm tước bỏ quyền chỉ huy của Thống đốc bang Arkansas Orval Faubus và gửi Quân đội Hoa Kỳ đến Arkansas để giúp đỡ họ thực hiện các mệnh lệnh của tòa án hạt liên bang nhằm xóa bỏ sự phân biệt chủng tộc tại trường Little Rock [11].

\subsubsection{Nhũng thẩm quyền thuộc về các bang}

Các quyền đặc biệt của các bang:

Theo pháp luật Hoa Kỳ, các tiểu bang được xem là các thực thể có chủ quyền, quyền lực của các tiểu bang được xem là đến trực tiếp tù̀ người dân trong các tiểu bang đó chứ không phải là từ chính quyền liên bang. Khi các tiểu bang có chủ quyền thành lập chính quyền Hoa Kỳ bằng việc chấp thuận thông qua Hiến pháp Hoa Kỳ, người dân của các tiểu bang đã chuyển giao một số quyền lực có giới hạn của chủ quyền tiểu bang sang cho chính quyền liên bang. Mặc dù pháp luật liên bang có hiệu lực cao hơn luật tiểu bang trong các lĩnh vực mà chính quyền liên bang được trao cho quyền hành động nhưng những quyền lực của chính quyền liên bang bị chi phối bởi chủ quyền có giới hạn mà Hiến pháp Hoa Kỳ đã quy định. Theo tu chính án 10 , những quyền lực không được các tiểu bang đồng ý trao cho chính quyền liên bang hoặc bị cấm chuyển giao, thì chúng thuộc về tiểu bang hoặc thuộc về nhân dân. Tu chính án 10 đã đặt ra những giới hạn rất rõ ràng cho quyền lực của chính quyền liên bang trong việc mở rộng thẩm quyền của mình. Tuy nhiên, trong quá trình thực thi quyền lực chính quyền, vẫn còn tồn tại nhiều khu vực mà quyền tài phán giữa liên bang và tiểu bang chồng chéo lên nhau. Tu chính án 10 cũng thường được dùng để hạn chế sự quản lý chồng chéo giữa chính quyền liên bang và chính quyền các tiểu bang, và hạn chế chính quyền liên bang quản lý can thiệp sâu vào hoạt động của chính quyền bang. Trong những năm gần đây, chính quyền liên bang đảm nhận trách nhiệm rộng lớn hơn trong những lĩnh vực như y tế, giáo dục, phúc lợi, giao thông, gia cư và phát triển đô thị. Do đó, bất cứ lĩnh vực nào chính quyền liên bang đảm nhận trách nhiệm trong lãnh thổ tiểu bang, các chương trình thường được duyệt xét trên căn bản hợp tác giữa hai cấp chính quyền hơn là một sự áp đặt từ chính quyền liên bang.

Trong lịch sử, các vụ việc bên trong địa giới tiểu bang là thuộc phạm vi quyền hạn của chính quyền tiểu bang, bao gồm: thành lập chính quyền địa phương; cấp các chứng nhận (lái xe, kêt hôn, v.v); điều chỉnh kinh doanh trong phạm vi bang; điều hành bầu cử; cung cấp các tiện ích công (giáo dục, y tế, giao thông và cơ sở hạ tầng); an ninh công cộng (kiềm chế tội phạm). Các lĩnh vực tiện ích công cộng và an ninh công cộng thường được xem là trách nhiệm chính của tiểu bang mặc dù tất cả những nhiệm vụ này hiện nay thường do chính quyền liên bang tài trợ và áp đặt những quy định khá nổi bật. Trong khuôn khổ này, chính quyền liên bang đảm bảo cho chính quyền tiểu bang mô hình thể chế cộng hoà, và luật lệ tiểu bang không được mâu thuẫn với hoặc vi phạm Hiến pháp liên bang hay luật lệ và các hiệp ước của Hợp Chủng Quốc Hoa Kỳ.

Cùng với thời gian, Hiến pháp Hoa Kỳ được tu chính nhiều lần dẫn đến kết quả là sự diễn giải và việc áp dụng các điều khoản của Hiến pháp cũng thay đổi theo. Xu hướng tổng thể hiện nay là đang dần hướng tới tổ chức quyền lực nhà nước tập trung và hợp nhất trong đó chính phủ liên bang đóng vai trò rộng lớn hơn nhiều so với trước đây. Tuy nhiên, hiện nay vẫn tiếp tục diễn ra các cuộc tranh luận về quyền của các tiểu bang liên quan đến bản chất quyền lực và chủ quyền của các tiểu bang so với chính quyền liên bang cũng như quyền của từng cá nhân.

Quyền lợ của chính quyền bang trong hệ thống liên bang:

Các tiểu bang có các quyền lợi và đặc quyền cụ thể được bảo đảm bởi hiến pháp liền bang và không thể bị tước đoạt bởi chính quyền liên bang nếu không có sự đồng thuận từ chính quyền bang. 
Chính quyền Cộng hòa - đây được coi nhu là một nhiệm vụ của Hoa Kỳ đảm bảo cho tất cả các tiểu bang trong liên minh dưới hình thức chính phủ cộng hòa, một nền chính phủ được cấu thành bởi những đại diện từ các tiểu bang. Trong một vài trường hợp khi những nền chính phủ đối lập đã được thành lập ở các tiểu bang, mỗi chính quyền đều khẳng định mình là một chính phủ hợp pháp và có quyền được nhân dân tuân thủ; chính phủ nào nhận được sự công nhận từ chính quyền liên bang sẽ chiếm ưu thế hơn.

Chống xâm lược - được coi như là một nhiệm vụ của chính quyền liên bang bảo vệ các tiểu bang khỏi chiến tranh xâm lược. Đây là một hành động đúng đắn và hợp lý, bởi vì các tiểu bang đã bị cấm sử dụng tàu chiến tranh hay bộ đội ky binh trong thời bình quy định bởi Hiến pháp.

Chống xung đột nội bộ - Đây được coi là một nhiệm vụ của chính quyền liên bang bảo vệ người dân của các tiểu bang khỏi xung đột nội bộ nảy sinh từ các cuộc khởi nghĩa hoặc bạo loạn, miễn là sự thi hành được quyết định bởi những nhà chức trách có quyền hạn ở các bang. Mục đích của điều khoản này là nhằm loại bỏ động cơ can thiệp vào các bang trong các vấn đề của tiểu bang vì những nguyên do chính trị hoặc những lý do khác đối lập với kì vọng của người dân ở tiểu bang. Thông thường cho việc đàn áp bạo loạn ở địa phương là trách nhiệm của cảnh sát trưởng ở các hạt hoặc thị trưởng của một thành phố, từ đó tận dụng được cảnh sát địa phương, và nếu cần thiết họ sẽ yêu cầu công dân hỗ trợ. Nếu điều này không hiệu quả, thống đốc sẽ được yêu cầu ra lệnh cho dân quân nhà nước để đàn áp các cuộc bạo loạn. Tuy nhiên, nếu cuộc bạo loạn vẫn lan rộng và sức mạnh của tiểu bang và các nhà chức trách địa phương là chưa đủ, thống đốc hoặc cơ quan lập pháp sẽ có quyền và nghĩa vụ kêu gọi sự trợ giúp về quân đội quốc gia từ Tổng thống Hoa Kỳ. Nếu theo đánh giá của tổng thống trong tình huống cần đảm bảo sự can thiệp của liên bang, tổng thống sẽ đưa ra quyết định điều chuyển quân đội từ địa bàn lân cận để lập lại trật tự. Rất nhiều lần trong lịch sử quân đội liền bang đã được sử dụng để dẹp bỏ các cuộc bạo loạn khi các nhà chức trách tại tiểu bang thể hiện sự bất lực của họ trong việc duy trì trật tự; hai ví dụ có thể kể đến cuộc đình công của những người thợ mỏ tại Nevada năm 1907 , và của Colorado năm 1914.

Thông thường tổng thống sẽ không có quyền can thiệp vào các vấn đề của tiểu bang cho đến khi nhận được sự cho phép từ phía thống đốc hoặc cơ quan lập pháp, tuy nhiên nếu như có sự xung đột làm ảnh hưởng đến sự vận hành của chính quyền liên bang hoặc sự vận hành thương mại liên tiểu bang, tổng thống có thể can thiệp bất cứ khi nào tổng thống cho rằng yêu cầu hành động từ liên bang trong trường hợp đó là cần thiết. Do đó trong suốt các cuộc bạo loạn đình công ở Chicago năm 1894, Tổng thống Cleveland đã ra lệnh cho quân đội liên bang đến thành phố, ngược lại với sự phản đối của thống đốc, với lý do cho rằng những kẻ đình công đang gây trở ngại cho việc vận hành thương mại liên tiểu bang cũng như thiếu tôn trọng pháp lệnh và bộ máy tòa án Hoa Kỳ. Sự can thiệp của tống thống đã bị một vài người phê phán, nhưng phần lớn người dân lại đồng tình với hướng đi này, và tòa án nhân dân tối cao Hoa Kỳ đã tôn trọng tính hợp lệ trong hành động của tổng thống.

Nhũng quyền khác của tiểu bang - Giữa những quyền lợi khác của tiểu bang dưới hiến pháp liên bang có thể đề cập đến quyền đại diện ngang nhau trong thượng viện - một quyền không thể bị loại bỏ khỏi các tiểu bang nếu không có sự chấp thuận từ tiểu bang.

Nghĩa vu và trách nhiệm của các tiểu bang với liên bang

Quyền lợi và quyền hạn thường đi kèm với nghĩa vụ, vì vậy chúng ta sẽ thấy được rằng các tiểu bang có một số nhiệm vụ nhất định với nhau và với liên bang, sự hài hòa cũng như thành công của hệ thống liên bang phụ thuộc phần lớn vào những nhiệm vụ được hoàn thành công bằng, đúng đắn.

Tính tín nhiệm - Trước hêt, mỗi tiểu bang phải luôn hành động với đầy đủ tín nhiệm, kể cả với thủ tục pháp lý và hồ sơ của các tiểu 
bang khác. Ví dụ, một bản sao hợp pháp có chứng thực của một di chúc sẽ được ghi nhận và quyền hạn sẽ được thi hành ở những tiểu bang khác theo đúng quy trình. Tương tự, một đám cưới được tổ chức hợp pháp tại một tiểu bang sẽ luôn được coi là hợp pháp ở một tiểu bang khác, và những sự kiện tại tòa cũng sẽ được ghi nhận ở các tiểu bang khác mà không cần có sự yêu cầu tái thẩm. Quy định về tín nhiệm đầy đủ không có nghĩa là một tiểu bang phải thi hành trong giới hạn luật pháp của những tiểu bang khác, hay việc đưa ra quyết định của tòa án bị ràng buộc bởi quyết định của tòa án trước đó ở những tiểu bang khác. Tuy nhiên, việc quyết định những vấn đề luật pháp khó khăn của tòa án ở một tiểu bang sẽ kiểm tra được những quyết định của tòa án ở những tiểu bang khác một cách cẩn thận theo cùng quan điểm, và đồng thời cho thấy được sự tôn trọng của họ đối với những quyết định này, mức độ tôn trọng phụ thuộc vào lập trường của các thẩm phán khi đưa ra quyết định và sự tương đồng về luật pháp và đạo luật của các tiểu bang liên quan.

Hiến pháp của mỗi tiểu bang ban hành luật về tội phạm chạy trốn khỏi tiểu bang này sang các tiểu bang khác, với mục đích để đưa về để tố tụng và chịu hình phạt tại tiểu bang nơi mà họ đã tẩu thoát. Yêu cầu dẫn giải được quyết định bởi thống đốc tại tiểu bang mà tên tội phạm đã chạy trốn, và người thống đốc đưa ra yêu cầu đó phải tuân thủ nó trừ khi có lý do chính đáng khác. Tuy nhiên, không còn cách nào khác để thi hành nghĩa vụ này, và cũng có nhiều trường hợp thống đốc sẽ từ chối giải phóng những kẻ tội phạm trốn thoát khỏi những tiểu bang khác - thường là bởi vì một lý do là, theo thống đốc, kẻ tẩu thoát sẽ không được nhận một án xử công bằng tại tiểu bang mà anh ta đã trốn thoát khỏi.

Quyền các công dân ở các tiểu bang khácMột trong nghĩa vụ được áp đặt bởi hiến pháp liên bang đối với các tiểu bang đó là đối đãi với công dân từ các tiểu bang khác như cách họ đối đãi với công dân của chính họ mà không có sự phân biệt đối xử. Nhưng nghĩa vụ này lại có liên quan đến quyền công dân nhiều hơn là đặc quyền chính trị. Nó không có nghĩa là một người mù chữ được phép bỏ phiếu tại Illinois lại có thể đến Massachusetts và bỏ phiếu nơi mà yêu cầu trình độ học vấn nhất định về bầu cử; nó cũng không có nghĩa là một người phụ nữ được thi hành luật tại một tiểu bang sau đó có thể thi hành nó ở tiểu bang khác nơi mà người phụ nữ không có quyền tham gia vào chuyên môn đó. Điều khoản này có nghĩa là bất kể đặc quyền hay sự miễn thuế nào mà tiểu bang cho phép công dân của mình, cũng là yêu cầu cho các công dân ở tiểu bang khác trong những điểu khoản tương tự, theo như những điều kiện tương tự và không hơn. Do đó tiểu bang không thể ép buộc công dân từ tiểu bang khác mức thuế cao hơn mức thuế áp dụng với công dân tiểu bang mình.

Nhũng nghĩa vu khác - Cuối cùng, đó là một điều hiển nhiên khi nhiệm vụ của mỗi tiểu bang là đối đãi với các tiểu bang khác trên tinh thần lịch thiệp, thực hiện những nhiệm vụ của hiến pháp liên bang liên quan đến bầu cử thượng nghị sĩ, đại biểu và bầu cử tổng thống để duy trì sự tồn tại của chính quyền liên bang.

\subsection{Nhũng thẩm quyền chung của của liên bang và các bang}

Chính quyền liên bang và chính quyền bang có sự chia sẻ quyền lực trên các lĩnh vực: Sức khỏe và y tế; Thuế; Thành lập các tòa án cấp dưới; Trừng phạt tội phạm; Xây dựng đường cao tốc [12].

Chính quyền liên bang (lập pháp liên bang, hành pháp liên bang và tòa án liên bang) chỉ có quyền hạn được quy định cụ thể trong Hiến pháp Hoa Kỳ. Vì thế mỗi khi Quốc hội Hoa Kỳ (lập pháp liên bang) thông qua một đạo luật, hay Tổng thống Hoa Kỳ (hành pháp liên bang) ban hành một pháp lệnh, hoặc Tòa án liên bang ra một phán quyết, mỗi hành động của chính quyền liên bang đều phải được quy định cụ thể trong Hiến pháp Hoa Kỳ. Còn với chính quyền tiểu bang, họ có thể làm bất cứ điều gì họ muốn, ngoại trừ những điều bị cấm cụ thể trong Hiến pháp Hoa Kỳ [13]. 
Từ những năm 1930, Tòa án Hoa Kỳ đã diễn giải các quy định về thương mại thuộc Hiến pháp Hoa Kỳ theo cách làm cho quyền lực liên bang mở rộng đáng kể. Ví dụ, Quốc hội Hoa Kỳ có thể đưa ra những quy định kiểm soát giao thông đường sắt nào chạy qua ranh giới giữa các tiểu bang. Tuy nhiên Quốc hội cũng có thể đưa ra những quy định kiểm soát giao thông đường sắt chỉ nằm hoàn toàn bên trong một tiểu bang, dựa trên ý tưởng cho rằng giao thông nằm hoàn toàn trong một tiểu bang vẫn có thể gây ra ảnh hướng đối với nền thương mại liên tiểu bang [14].

Quyền thu thuế và chi trả cho trị an cuộc sống là một trong những quyền chia sẻ giữa liên bang và tiểu bang nhưng lại là một quyền có điều kiện của Quốc hội Hoa Kỳ. Quốc hội Hoa Kỳ (liên bang) được Hiến pháp giao quyền “đặt ra thuế và thu thuế để trả nợ và cung cấp cho trị an cuộc sống ở Hoa Kỳ" (khoản 8 Điều I Hiến pháp). Tuy nhiên quyền "đặt ra thuế và thu thuế" này phải được dùng cho việc "trả nợ và cung cấp cho trị an cuộc sống”. Nói cách khác, chỉ khi nào chính quyền liên bang "cung cấp cho trị an cuộc sống" thì mới được quyền đặt ra các loại thuế và thu thuế [15].

Xây dựng đường cao tốc là một trong những thẩm quyền chia sẻ giữa liên bang và tiểu bang trong đó chính quyền liên bang chịu trách nhiệm tài trợ và quản lý. Tuy nhiên, hệ thống đường cao tốc cũng phục lợi ích các tiểu bang nên các tiểu bang chia sẻ với liên bang trách nhiệm xây dựng hệ thống này trong phạm vi các tiểu bang. Ngân sách cho việc xây dựng này ở tiểu bang được Quốc hội phân phát trở lại cho các tiểu bang từ nguồn tiền thuế thu được trên khắp Hoa Kỳ [16].

Tóm lại, trong chế độ liên bang, chính quyền bang và chính quyền tiểu bang chia sẻ một số quyền lực dựa theo phạm vi trách nhiệm của mình. Tuy nhiên, theo Hiến pháp Hoa Kỳ, trong số các quyền lực chia sẻ này, nếu xảy ra xung đột giữa thẩm quyền liên bang và thẩm quyền tiểu bang thì thẩm quyền của chính quyền liên bang được ưu tiên hơn.

\subsection{Một số nhận xét về phân cấp chính quyền Hoa Kỳ}

Nghiên cứu về phân cấp chính quyền Hoa Kỳ, có thể rút ra những đặc điểm trong tổ chức và phương thức hoạt động của bộ máy chính quyền như sau:

Thứ nhất, phân cấp chính quyền Hoa Kỳ đã tạo ra được một cơ chế kiểm soát quyền lực hiệu quả. Tính hiệu quả thể hiện ở các điểm sau:

+ Chính quyền Hoa Kỳ hiện nay vẫn giữ nguyên những nguyên tắc đã được định hình từ thời lập quốc, đó là: tự do dân chủ, chế độ liên bang, quyền của người dân, ...V Vận dụng học thuyết phân quyền của Montesquieu trong tổ chức, vận hành bộ máy nhà nước ở cả chính quyền liên bang lẫn chính quyền bang. Nguyên tắc tam quyền phân lập triệt để cùng với cơ chế kiểm soát và cân bằng giữa các nhánh quyền lực đã tạo ra một cơ chể kiểm soát quyền lực hữu hiệu ngay trong bản thân bộ máy nhà nước. Cơ chế này không cho phép quyền lực tập trung quá nhiều trong tay một cá nhân hay một cơ quan nào. Ba cơ quan lập pháp, hành pháp và tư pháp được phân quyền rành mạch, rõ ràng đã làm hạn chế một cách đáng kể khả năng lạm dụng quyền lực của các cơ quan công quyền.

+ Ngành lập pháp (cả chính quyền liên bang lẫn tiểu bang) đều được tổ chức và hoạt động với cơ chế lưỡng viện nhằm tạo ra sự cân bằng quyền lực giữa Thượng viện và Hạ viện. Việc thiết lập lưỡng viện với cơ chế kiềm chế nhau giữa các viện sẽ ngăn chặn được quyền lực tập trung trong tay một viện hoặc một thiết chế, vừa tạo được sự cân bằng và kiểm soát lẫn nhau trong cơ cấu ngành lập pháp, đồng thời làm giảm bớt ưu thế của cơ quan lập pháp, từ đó tạo sự cân bằng với bộ máy hành pháp. Cơ chế lưỡng viện cũng giúp cho quá trình làm luật chặt chẽ hơn, khắc phục được những khiếm khuyết của quy trình lập pháp, thỏa mãn được lợi ích nhiều đảng phái và tầng lớp trong xã hội. Trong cơ cấu lưỡng viện thì Thượng viện được xem là cơ quan đại diện quyền lực nhà nước ở Trung ương, còn Hạ viện là đại diện cho quyền lực của nhân dân. Chính vì vậy mà Hạ viện thường giữ vai trò quan trọng hơn Thượng viện 
(thể hiện ở chỗ khả năng quyết định của Hạ viện là luôn cao hơn Thượng viện). Điều này rất hợp lý và phù hợp với nguyên tắc về sự ủy quyền và nhận sự ủy quyền. Hạ viện hay còn gọi là Viện dân biểu là do nhân dân bầu ra, nhận sự ủy quyền trực tiếp từ nhân dân, do vậy phải là cơ quan có thực quyền hơn Thượng viện nhận sự ủy quyền gián tiếp.

+ Phương thức tổ chức và hoạt động chính quyền Hoa Kỳ đã tạo ra cơ quan bảo hiến - là cơ quan có quyền luận tội người đứng đầu nhánh hành pháp nếu có vi phạm pháp luật. Có thể nói, sự hiện diện của cơ quan bảo hiến đã trở nên vô cùng cần thiết trong cơ chế kiểm soát quyền lực ở Hoa Kỳ. Tòa án Hiến pháp Hoa Kỳ có thẩm quyền buộc Tổng thống Hoa Kỳ phải trực tiếp điều trần trước Tòa án Hiến pháp và Thượng viện. Tòa án Hiến pháp có thẩm quyền xét xử và đưa ra kết luận những hành vi vi hiến. Với truyền thống coi trọng pháp luật và Hiến pháp thì rõ ràng cơ chế này tỏ ra rất hiệu quả trong việc kiểm soát quyền lực.

Thư hai, cơ quan tư pháp Hoa Kỳ tồn tại dựa trên nguyên tắc độc lập và không bị ảnh hưởng bởi các thiết chế chính trị khác, tuân thủ Hiến pháp và pháp luật. Đây là nguyên tắc sống còn của nền tư pháp Hoa Kỳ. Ngoài việc độc lập với hành pháp và lập pháp thì sự độc lập của tòa án còn thể hiện ngay trong hệ thống tư pháp. Tòa án tiểu bang độc lập với tòa án liên bang, các tòa án cấp dưới không phải là bộ phận của tòa án cấp trên. Khi hoạt động, các tòa án cấp dưới chỉ tuân theo Hiến pháp và pháp luật, căn cứ theo thẩm quyền của mình đã được pháp luật quy định.

Thú $b a$, Hoa Kỳ là nhà nước thượng tôn pháp luật. Thật vậy, chính quyền Hoa Kỳ được thành lập bởi Hiến pháp 1787, tổ chức và hoạt động của chính quyền đều được quy định bởi Hiến pháp và các đạo luật liên quan. Đến lượt mình, chính quyền Hoa Kỳ quản lý xã hội bằng pháp luật. Hiến pháp và pháp luật là căn cứ, cơ sở để chính quyền tạo ra khung pháp lý điều chỉnh các mối quan hệ trong xã hội, điều phối quan hệ giữa các cấp bậc chính quyền. Các tổ chức và các đảng phái được tự do thành lập trên cơ sở căn cứ quy định của pháp luật.
Thư tur, Nhà nước liên bang Hoa Kỳ có tính ổn định cao trong xác lập địa giới hành chính lãnh thổ và vận hành quyền lực nhà nước. Hiến pháp Hoa Kỳ quy định các bang có quyền tự do gia nhập liên bang nhưng không được quyền tự ý ra khỏi liên bang. Quy định này nhằm đảm bảo các bang trong liên bang hướng tới một liên kết bền vững, cùng nhau chia sẻ những cam kết chung. Bên cạnh đó, những nguyên tắc của Hiến pháp Hoa Kỳ cho phép bộ máy nhà nước vận hành một cách ổn định, không bị xáo trộn trước những biến động của tình hình quốc tế, hay sự thay đổi của các nhà cầm quyền trong nước. Cho dù các nhà cầm quyền đại diện cho đảng phái chính trị nào và có thể bị thay thế liên tục qua các kỳ bầu cử thì họ vẫn phải tuân thủ Hiến pháp và pháp luật, chỉ được hoạt động trong phạm vi pháp luật cho phép và luôn có những cơ chế kiểm soát quyền lực của họ. Mặc dù các đảng phái chính trị luôn cạnh tranh nhau giành quyền kiểm soát bộ máy nhà nước nhưng họ vẫn cùng nhau hướng tới những giá trị cơ bản của xã hội, đó là chế độ cộng hòa, tôn trọng hiến pháp và các nguyên tắc của hiến pháp, ủng hộ chế độ sở hữu tư nhân, phát triển nền kinh tế thị trường, ủng hộ luật pháp và trật tự. Tính ổn định cao của bộ máy nhà nước là cơ sở quan trọng giúp cho Hoa Kỳ trở thành một trong những cường quốc kinh tế và chính trị hàng đầu thế giới [17].

Thư năm, thực tế việc thực hiện phân chia quyền lực giữa chính quyền liên bang và chính quyền các bang đến nay cho thấy quyền lực của chính quyền trung ương ngày càng tăng. Ngoài những quyền chủ yếu về quân sự và chính sách đối ngoại, chính quyền liên bang còn có ưu thế về tài chính, có thể phân bổ trợ giúp về tài chính cho các bang [18].

\subsection{Kết luận về phân cấp chính quyền Hoa Kỳ}

Hiến pháp liên bang và tiểu bang có mối quan hệ mật thiết về mặt lịch sử, truyền thống và văn kiện. Bảo đảm quyền của cấp tiểu bang là mô hình được nhắc đến trong Bản tuyên ngôn và Hiến pháp Hoa Kỳ. Theo Brennan (1977), trước khi thông qua hiến pháp liên bang, mối quyền được công nhận trong Bản tuyên ngôn 
trước đó đều được bảo đảm trong hiến pháp của nhiều tiểu bang. Hiến pháp Hoa Kỳ thành lập dựa trên hình thức nhà nước liên bang về chia sẻ quyền lực giữa chính quyền chính quyền liên bang và chính quyền bang. Mỗi bang của Hoa Kỳ có hiến pháp riêng, mỗi điều khoản trong hiến pháp bang phải tuân theo Hiến pháp liên bang. Tuy nhiên vì nhiều lý do khác nhau cùng với những tranh luận về việc suy giảm quyền hạn của tiểu bang, vai trò của hiến pháp liên bang đã phát triển và trở thành trọng tâm.

Dưới hiến pháp Hoa Kỳ, một số quyền lực được chỉ định riêng cho chính quyền liên bang và chính quyền tiểu bang, một số quyền lực khác được chia sẻ giữa hai cấp chính quyền. Nhìn chung, Hiến pháp Hoa Kỳ đảm bảo rằng việc giải quyết các vấn đề quốc gia dành riêng cho chính quyền liên bang, trong khi các chính quyền bang có quyền giải quyết các vấn đề liên quan đến ảnh hưởng tại chính bang đó. Quyền lực của chính quyền liên bang gồm: in tiền, tuyên bố chuyến tranh, thành lập quân đội, ký kết với các chính quyền nước khác, điều chỉnh thương mại giữa các bang và thương mại quốc tế, thành lập bưu điện, đưa ra các luật cần thiết nhằm củng cố Hiến pháp. Các quyền lực cụ thể được chỉ định chính quyền bang gồm: thành lập chính quyền địa phương, cấp các chứng nhận (lái xe, kết hôn, v.v), điều chỉnh kinh doanh trong phạm vi bang, điều hành bầu cử, tuân thủ các điều khoản quy định trong hiến pháp liên bang, cung cấp các dịch vụ y tế công và an ninh công cộng. Quyền lực được thực thi bởi cả chính quyền liên bang và bang là thành lập tòa án, xây dựng đường cao tốc, vay mượn tiền, thi hành luật, hoạt động ngân hàng và doanh nghiệp, trợ cấp, bồi hoàn tài sản tư nhân.

Mối quan hệ giữa chính quyền liên bang và chính quyền bang của Hoa Kỳ được tuân theo hệ thống liên bang, chính quyền liên bang không nắm giữ tất cả quyền lực mà chia sẻ quyền lực với các bang, và các bang của Hoa Kỳ được coi là có chủ quyền riêng. Chính quyền liên bang cho phép các bang tự do tạo ra luật có chủ quyền riêng của mình dựa trên nhu cầu và mong muốn riêng của từng bang. Hay còn được gọi là tuân theo chủ nghĩa liên bang.
Trên thực tế, tòa án tiểu bang có xu hướng công nhận vắn kiện liên bang nhưng không có nghĩa tiểu bang có nghĩa vụ phải tuân theo. Theo Breannan (1977), các tòa án tiểu bang được tự phép mở rộng hoặc thu hẹp quyền hiến pháp bang so với những quyền hạn được đảm bảo bởi tòa án liên bang. Tuy nhiên trong thực tế, các tòa án bang thường tuân theo luật hiến pháp liên bang vì tính thuyết phục mạnh mẽ của hiến pháp liên bang.

Các chính quyền dưới tiểu bang không được đưa ra chủ quyền riêng trong một bang. Chính quyền dưới tiểu bang chỉ đơn thuần là được ủy nhiệm quyền hạn từ nhà nước cho khu vực dưới tiểu bang. Chính quyền bang có thể bãi bỏ hoặc giải tán chính quyền chính quyền dưới tiểu bang nhưng chính quyền trung ương không có quyền loại bỏ chính quyền bang. Dù chính quyền liên bang và tiểu bang chia sẻ quyền lực, chính quyền dưới tiểu bang phải được đảm bảo bởi quyền lực của chính quyền bang. Các chính quyền hạt được tổ chức bởi chính quyền dưới tiểu bang và được quy định trong hiến pháp bang. Trong đa số các bang, chính quyền hạt và thành phố có sự chia sẻ quyền hành vì các thành phố thuộc sự quản lý của các hạt. Tuy nhiên, trong một số bang, ví dụ bang Vỉginia, thành phố độc lập so với chức năng hoạt động của chính quyền hạt.

Ngân sách là sự ưu tiên đầu tiên trong việc các chính quyền liên bang và chính quyền bang kiểm soát chính sách và các ưu tiên của mình. Bằng cách trực tiếp hoặc gián tiếp, tất cả các chính sách của các cấp chính quyền đều liên quan đến ngân sách. Không giông như chính quyền liên bang có thể chấp nhận thâm hụt ngân sách để đầu tư cho hoạt động hàng ngày, chính quyền bang phải hoạt động theo luật pháp giới hạn bởi "cân bằng ngân sách", nghĩa là các chi phí không được vượt quá doanh thu thuế trong năm tài khóa. Ngày bắt đầu và kết thúc năm tài khóa khác nhau giữa chính quyền liên bang (từ $01 / 10$ đến $030 / 9$ năm sau) và chính quyền bang (đa số chọn năm tài khóa bắt đầu từ 01/07 đến 30/06). Trong một số trường hợp, chính quyền bang cũng có chu kỳ ngân sách hai 
năm. Chu kỳ ngân sách ảnh hưởng đến quyết định của mọi cấp chính quyền Hoa Kỳ.

\section{Kiến nghị phân cấp tổ chức Nhà nước tại Việt Nam}

\subsection{Phân cấp quản lý Nhà nuoóc Việt Nam}

Theo Nguyễn Cửu Việt - Trường Đại học Luật thành phố Hồ chí Minh, Phân cấp quản lý là sự phân chia các đơn vị hành chính - lãnh thổ và sự phân định thẩm quyền hợp lý giữa các cấp chính quyền bằng luật hoặc bằng văn bản dưới luật cho phù hợp với chức năng, nhiệm vụ và đặc điểm của mỗi cấp để nhằm thực thi hiệu quả hơn quyền lực nhà nước [19].

Nhà nước Việt Nam được tổ chức theo hình thức cấu trúc đơn nhất. Đặc trưng của hình thức nhà nước đơn nhất là quyền lực tập trung, thống nhất. Nguyên tắc cơ bản trong tổ chức hoạt động bộ máy nhà nước là "tập trung dân chủ". Vì vậy, chính quyền trung ương có chức năng quản lý và điều hành đất nước trên tất cả các lĩnh vực: kinh tế, xã hội, an ninh, quốc phòng, đối nội, đối ngoại, ... thông qua việc ban hành hệ thống pháp luật; xây dựng hệ thống chính sách; quản lý các nguồn lực chủ yếu của đất nước; lập quy hoạch, kế hoạch trong từng lĩnh vực; trực tiếp thực hiện các nhiệm vụ mang tầm quốc gia; quản lý và điều hành hệ thống chính quyền địa phương nhằm đảm bảo cho các chính sách và kế hoạch của Nhà nước được thực thi theo đúng pháp luật.

\section{2. Đặc điểm phân cấp quản lý Nhà nuớc Việt Nam}

Phân cấp quản lý Nhà nước Việt Nam có những đặc điểm cơ bản sau:

- Đất nước được phân chia thành nhiều cấp, các cấp chính quyền đều là bộ phận cấu thành của nhà nước Việt Nam thống nhất, ở mỗi cấp chính quyền đều có cơ quan đại diện là Hội đồng nhân dân (HĐND) và cơ quan hành chính là Ưy ban nhân dân (UBND). Mỗi địa phương đều có ngân sách, song chúng phải được cơ quan đại diện cao nhất ở trung ương là Quốc hội phê duyệt trong tổng thể ngân sách của nhà nước.

- Các cơ quan hành chính nhà nước ở địa phương (Ủy ban nhân dân) đều được tổ chức và hoạt động theo nguyên tắc song trùng trực thuộc: Vừa trực thuộc cơ quan hành chính nhà nước cấp trên vừa trực thuộc cơ quan đại diện cùng cấp là Hội đồng nhân dân [20].

- Theo Hiến pháp năm 2013, ở nước ta có các loại cơ quan nhà nước sau:

+ Cơ quan quyền lực hay còn gọi là các cơ quan đại diện (lập pháp): bao gồm Quốc hội ở cấp trung ương và Hội đồng nhân dân các cấp địa phương do nhân dân trực tiếp bầu ra và thay mặt nhân dân thực hiện quyền lực nhà nước.

+ Cơ quan hành chính (hành pháp): bao gồm Chính phủ ở cấp trung ương và Ưy ban nhân dân các cấp địa phương do cơ quan quyền lực tương ứng bầu ra.

+ Cơ quan xét xử (tư pháp): bao gồm Tòa án Nhân dân Tối cao (TANDTC) ở cấp trung ương và Toà án nhân dân các cấp địa phương.

+ Cơ quan kiểm sát (công tố): bao gồm Viện Kiểm sát Nhân dân Tối cao (VKSNDTC) ở cấp trung ương và Viện kiểm sát nhân dân các cấp địa phương.

+ Chủ tịch nước là một chức vụ nhà nước, một cơ quan đặc biệt thể hiện sự thống nhất quyền lực, có những hoạt động thực hiện quyền lập pháp, hành pháp và tư pháp nên không xếp vào bất kỳ một loại cơ quan nào.

- Tổ chức Nhà nước cấp trung ương:

Quốc hội

Quốc hội Việt Nam theo mô hình đơn viện và là cơ quan hành chính quyền lực nhà nước cao nhất. Quốc hội Việt Nam có 3 nhiệm vụ chính: (i) Lập hiến, Lập pháp; (ii) Quyết định các vấn đề quan trọng của đất nước; (iii) Giám sát tối cao hoạt động của Nhà nước.

Thành phần nhân sự của Quốc hội là các đại biểu, do cử tri Việt Nam bầu ra theo nguyên tắc phổ thông, bình đẳng, trực tiếp và bỏ phiếu kín. Các đại biểu được bầu chịu trách nhiệm trước 
cử tri bầu ra mình và trước cử tri cả nước, có nhiệm kỳ 5 năm. Hiện nay, Quốc hội Việt Nam có 500 đại biểu.

Đứng đầu Quốc hội Việt Nam là Chủ tịch Quốc hội do các đại biểu quốc hội bầu ra [21].

\section{Chinh phu}

Chính phủ Việt Nam là cơ quan chấp hành của Quốc hội Việt Nam và được xem là cơ quan hành chính nhà nước cao nhất. Chính phủ chịu sự giám sát của Quốc hội và Chủ tịch nước. Chính phủ phải chấp hành: (i) Hiến pháp, luật, nghị quyết của Quốc hội; (ii) Pháp lệnh, nghị quyết của Ủy ban Thường vụ Quốc hội; (iii) Lệnh, quyết định của Chủ tịch nước. Chính phủ Việt Nam được thành lập trong kỳ họp thứ nhất của Quốc hội mỗi khóa và có nhiệm kỳ là 5 năm.

Đứng đầu Chính phủ Việt Nam là Thủ tướng Chính phủ. Thủ tướng Chính phủ do Chủ tịch nước đề cử và Quốc hội phê chuẩn. Các Phó thủ tướng do Thủ tướng chỉ định. Các thành viên Chính phủ do Chủ tịch nước chỉ định theo đề xuất của Thủ tướng và được Quốc hội phê chuẩn [22].

\section{Tòa án nhân dân tối cao}

Tòa án nhân dân tối cao Việt Nam là cơ quan xét xử nhà nước cao nhất và có những nhiệm vụ và quyền hạn sau: (i) Hướng dẫn các Tòa án áp dụng thống nhất pháp luật, tổng kết kinh nghiệm xét xử của các Tòa án; (ii) Giám đốc việc xét xử của các Tòa án các cấp; giám đốc việc xét xử của Tòa án đặc biệt và các Tòa án khác, trừ trường hợp có quy định khác khi thành lập các Tòa án đó; (iii) Trình Quốc hội dự án luật và trình Ủy ban thường vụ Quốc hội dự án pháp lệnh theo quy định của pháp luật; (iv) Đứng đầu Tòa án Tối cao là Chánh án Tối cao. Chánh án Tối cao do Chủ tịch nước đề cử và Quốc hội phê chuẩn [23].

\section{Viện kiểm sát nhân dân tối cao}

Viện kiểm sát nhân dân tối cao là cơ quan kiểm sát và công tố nhà nước cao nhất.

Viện kiểm sát có thẩm quyền công tố và kiểm sát hoạt động tư pháp: (i) Thực hành quyền công tố, kiểm sát hoạt động tư pháp của nước Cộng hòa xã hội chủ nghĩa Việt Nam; (ii) Bảo vệ Hiến pháp và pháp luật, bảo vệ quyền con người, quyền công dân, bảo vệ chế độ xã hội chủ nghĩa, bảo vệ lợi ích của Nhà nước, quyền và lợi ích hợp pháp của tổ chức, cá nhân, góp phần bảo đảm pháp luật được chấp hành nghiêm chỉnh và thống nhất.

Đứng đầu Viện kiểm sát nhân dân tối cao là Viện trưởng Viện kiểm sát nhân dân tối cao do Chủ tịch nước bổ nhiệm theo Hiến pháp [24].

\section{- Tổ chức Nhà nước tại địa phuoong}

Theo Luật tổ chức chính quyền địa phương 2015, Việt Nam hiện nay có 3 cấp địa phương là cấp tỉnh (tỉnh và thành phố trực thuộc trung ương), cấp huyện (thành phố thuộc tỉnh, thị xã, quận và huyện) và cấp xã (xã, phường và thị trấn). Tại mỗi cấp có các cơ quan tương ứng là Hội đồng nhân dân, Ủy ban nhân dân, Tòa án nhân dân và Viện kiểm sát nhân dân.

\section{Hội đồng nhân dân}

Hội đồng nhân dân là cơ quan quyền lực tại cấp tỉnh, huyện và xã. Đại biểu HĐND do cử tri khu vực đó bầu lên với nhiệm kỳ 5 năm. Đứng đầu HĐND là Chủ tịch HĐND do các đại biểu bầu ra.

\section{Ủy ban nhân dân}

Ủy ban nhân dân là cơ quan hành chính tại cấp tỉnh, huyện và xã. Đứng đầu UBND là Chủ tịch UBND do Hội đồng Nhân dân cấp đó bầu ra.

\section{Tòa án nhân dân}

Tòa án nhân dân là cơ quan xét xử tại cấp tỉnh và huyện. Đứng đầu TAND là Chánh án do Chánh án Tối cao bổ nhiệm.

\subsection{Mối quan hệ giũa chính quyền trung uơng và chính quyền địa phuoong ở Việt Nam}

Theo quy định của pháp luật, Quốc hội là cơ quan quyền lực cao nhất của nhà nước và là đại diện cao nhất của nhân dân. Quốc hội có chức năng lập hiến, lập pháp và quyết định những vấn đề quan trọng của đất nước. Các cơ quan, tổ chức, cá nhân trên toàn quốc có trách nhiệm tuân thủ các pháp lệnh và nghị quyết của Quốc hội. 
Chính phủ là cơ quan chấp hành của Quốc hội, cơ quan hành chính Nhà nước cao nhất của nước Cộng hòa xã hội chủ nghĩa Việt Nam. Với chức năng thống nhất quản lý việc thực hiện các nhiệm vụ chính trị, kinh tế, văn hóa, xã hội, quốc phòng, an ninh, đối ngoại của Nhà nước, Chính phủ ban hành các chính sách quy hoạch, kế hoạch và bảo đảm các điều kiện để chính quyền địa phương thực hiện các mục tiêu chung của đất nước và quản lý Nhà nước ở địa phương. Việc thành lập mới, sáp nhập, chia tách địa giới hành chính; phân công, phân cấp quản lý trong hệ thống hành chính; quy định về tổ chức hoạt động của Hội đồng nhân dân và Uỷ ban nhần dân và các bộ, ngành, ... đều do Chính phủ quyết định.

Việc tổ chức thực hiện và kiểm soát quyền lực Nhà nước không chỉ thực hiện theo chiều ngang giữa các cơ quan lập pháp, hành pháp và tư pháp mà còn được thực hiện theo chiều dọc:

- Quốc hội giám sát toàn bộ hoạt động của Nhà nước; UBTVQH giám sát hoạt động của HĐND cấp tỉnh và có quyền bãi bỏ một phần hoặc toàn bộ nghị quyết của HĐND cấp tỉnh. Trong trường hợp HĐND cấp tỉnh có sai phạm nghiêm trọng ảnh hưởng đến lợi ích của nhân dân, UBTVQH có quyền giải tán HĐND đó.

- Chính phủ thực hiện quyền kiểm tra HĐND cấp tỉnh trong việc thực hiện Hiến pháp, luật, nghị quyết của Quốc hội; các quyết định của Chủ tịch nước; nghị định, nghị quyết, chỉ thị của Chính phủ và Thủ tướng chính phủ; và kiểm tra tính hợp pháp của các nghị quyết của HĐND cấp tỉnh. Chính phủ có quyền đình chỉ thi hành hoặc bãi bỏ các quyết định, nghị quyết sai trái của UBND và HĐND cấp tỉnh.

- Sự kiểm tra, giám sát theo chiều dọc còn thực hiện thông qua công tác nhân sự: UBTVQH phê chuẩn các chức danh trong Thường trực HĐND. Thủ tướng chính phủ phê chuẩn kết quả bầu Chủ tịch và các thành viên UBND. Thủ tướng chính phủ có quyền điều động, cách chức Chủ tịch và các Phó chủ tịch UBND cấp tỉnh.

Mặc dù chính quyền Trung ương giữ vai trò lãnh đạo, chỉ đạo và thực hiện việc giám sát, kiểm tra đối với chính quyền địa phương nhưng chính quyền địa phương cũng có sự độc lập nhất định trong việc quyết định, quản lý Nhà nước về kinh tế - xã hội ở địa phương theo quy định của pháp luật. Ngoài việc thực hiện đúng theo chủ trương của Nhà nước, HĐND cấp tỉnh còn có thẩm quyền quyết định các chủ trương, biện pháp có tính chất đặc thù nhằm phát huy tiềm năng của địa phương. Sự độc lập nhất định còn thể hiện ở việc chịu trách nhiệm trước chính quyền Trung ương về kết quả hoạt động của mình.

\subsection{Nhũng điểm tương đồng và khác biệt trong phân cấp chính quyền ở Hoa Kỳ và ở Việt Nam}

\section{Hiến pháp và tính tối cao của pháp luật}

Mặc dù Hoa Kỳ và Việt Nam có hệ tư tưởng và chế độ xã hội không giống nhau nhưng cả hai nước đều đề cao giá trị của Hiến pháp và pháp luật. Hiến pháp và pháp luật là cơ sở và căn cứ cho mọi hoạt động, tổ chức của nhà nước. Hiến pháp là văn bản pháp lý có hiệu lực cao nhất ở cả Hoa Kỳ và Việt Nam. Điều này đồng nghĩa với tất cả các văn bản pháp lý khác (kể cả điều ước quốc tế) phải tuân thủ các quy định của Hiến pháp.

Ở Việt Nam, tính tối cao của Hiến pháp được quy định rõ ràng tại điều 119 , Hiến pháp 2013: "Hiến pháp là luật co bản của nước Cộng hoà xã hội chủ nghĩa Việt Nam, có hiệu lưc pháp lý cao nhất. Moi văn bản pháp luật khác phải phù hợp với Hiến pháp”.

Điều VI Hiến pháp Hoa Kỳ quy định về điều khoản tối cao như sau: "Hiến pháp này, và các luật của Hợp chúng quốc được xây dưng trên $c o^{\circ}$ sở tuân thủ Hiến pháp, và tất cả các hiệp uoớc đã được ký kết hoặc sẽ được ký kết, với tu cách thẩm quyền Hợp chúng quốc, sẽ là luật tối cao của tồ quốc; và mang tính ràng buộc đối với thẩm phán ở tất cả các bang, cho dù trong Hiến pháp và luật của các bang có bất cứ nội dung gì trái ngượ".

Quy định này đã thiết lập nguyên tắc tiên quyết của pháp luật Hoa Kỳ: mọi hoạt động của chính quyền liên bang và chính quyền bang đều phải tuân thủ Hiến pháp; Hiến pháp và pháp 
luật các tiểu bang không được phép có nội dung xung đột với Hiến pháp liên bang.

Sư phân chia quyền lực trong tổ chức hoạt động của bộ máy chính quyền

Chính quyền Hoa Kỳ phân cấp rõ ràng về quyền lập pháp, hành pháp, tư pháp trong bộ máy chính quyền trung ương và bộ máy chính quyền ở từng tiểu bang (Sơ đồ 3.1). Hiến pháp Hoa Kỳ quy định tất cả các quyền lập pháp đều thuộc về Quốc hội bao gồm thượng viện và hạ viện. Cơ quan lập pháp được đặc trưng bởi hệ thống lưỡng viện nhằm đảm bảo quyền lực được cân bằng. Quyền hành pháp liên bang thuộc về Tổng thống và gần như độc lập với Quốc hội. Quyền tư pháp thuộc về tòa án tối cao và các tòa án cấp dưới. Ngoài ra, Quốc hội có chức năng giám sát hoạt động của bộ máy hành pháp và tư pháp. Theo Hiến pháp Hoa Kỳ, Tổng thống có quyền phủ quyết dự luật được Quốc hội liên bang thông qua. Tòa án tối cao có quyền tuyên bố các luật vi hiến của chính phủ, thẩm phán liên bang được phê duyệt bởi bên lập pháp, bên hành pháp có quyền bổ nhiệm thẩm phán. Tam quyền phân lập giúp cho chính quyền Hoa Kỳ vận hành độc lập, không bị chi phối bởi bất cứ quyền lực nào, đồng thời có thể giám sát hoạt động lẫn nhau (Sơ đồ 3.1).

Trong khi đó, quyền lực nhà nước Việt Nam là thống nhất. Hiến pháp Việt Nam năm 2013 quy định Quốc hội đóng vai trò là cơ quan quyền lực nhà nước cao nhất và thực hiện quyền giám sát tối cao đối với toàn bộ hoạt động của Nhà nước (Sơ đồ 3.3 ). Quyền hành pháp hay cơ quan hành chính nhà nước cao nhất của nhà nước Việt Nam là Chính phủ, là cơ quan chấp hành của Quốc hội. Bộ máy chính phủ gồm có Thủ tướng Chính phủ, Các phó Thủ tướng, các Bộ trưởng và Thủ trưởng cơ quan ngang bộ. Tòa án nhân dân thực hiện quyền tư pháp. Việc phân định quyền hạn nhà nước nhằm mục địch hoạt động hiểu quả, đảm bảo tính pháp quyền của nhà nước, phối hợp thống nhất vì mục tiêu chính trị chung.

Trong việc ban hành các văn bản pháp luật tại Việt Nam, các văn bản do Quốc hội ban hành có giá trị pháp lý cao nhất, Quốc hội quyết định những chính sách cơ bản. Nhưng theo Hiến pháp Hoa Kỳ, việc Quốc hội thông qua một văn bản pháp luật cần sự thông qua của Thượng Viện và Hạ Viện, và Tổng thống có thể phủ quyết dự luật.

Trong hệ thống hành pháp, chính phủ Việt Nam có quyền ban hành văn bản quy phạm pháp luật như Nghị định Chính phủ của Thủ tướng, Thông tư của Bộ trưởng các Bộ. Các văn bản này có hiệu lực pháp lý thấp hơn so với văn bản của Quốc hội và Ưy ban thường vụ Quốc hội. Quyền hành pháp của Hoa Kỳ thuộc về Tổng thống Hoa Kỳ.

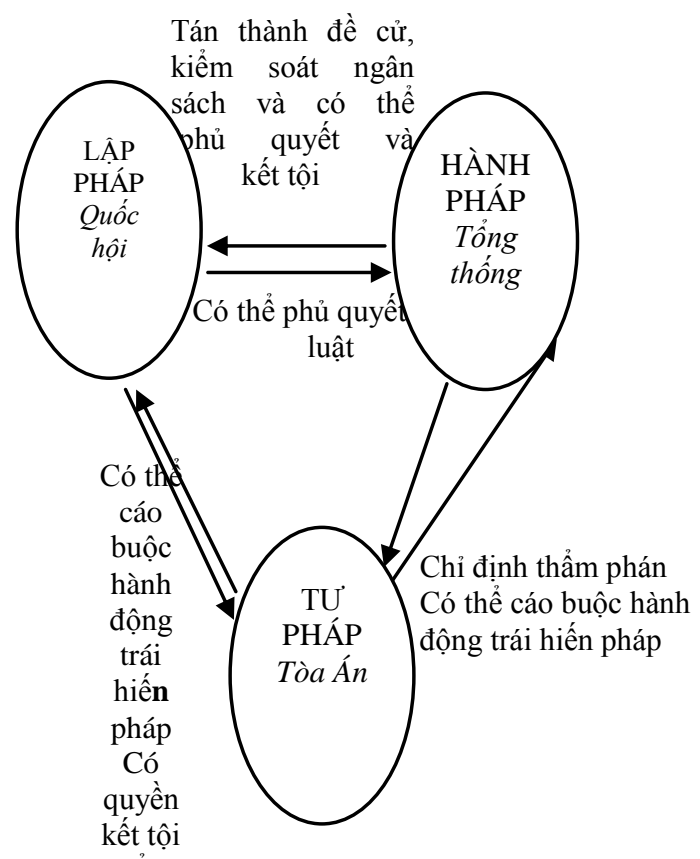

Sơ đồ 3.1. Sự phân cấp, chia sẻ quyền lực giữa chính quyền trung ương và chính quyền bang của chính quyền Hoa Kỳ.

Trong hệ thống tư pháp, Việt Nam có hai thiết chế trong hệ thống tư pháp: Viện kiểm soát và Tòa án. Hội đồng thẩm phán Tòa án nhân dân tối cao có thẩm quyền ban hành Nghị quyết. Trong hệ thống tư pháp của Hoa Kỳ, các bang có tòa án tại mỗi bang, tòa án liên bang sẽ có thẩm quyền xét xử nếu tranh chấp giữa công dân của hai bang khác nhau. 


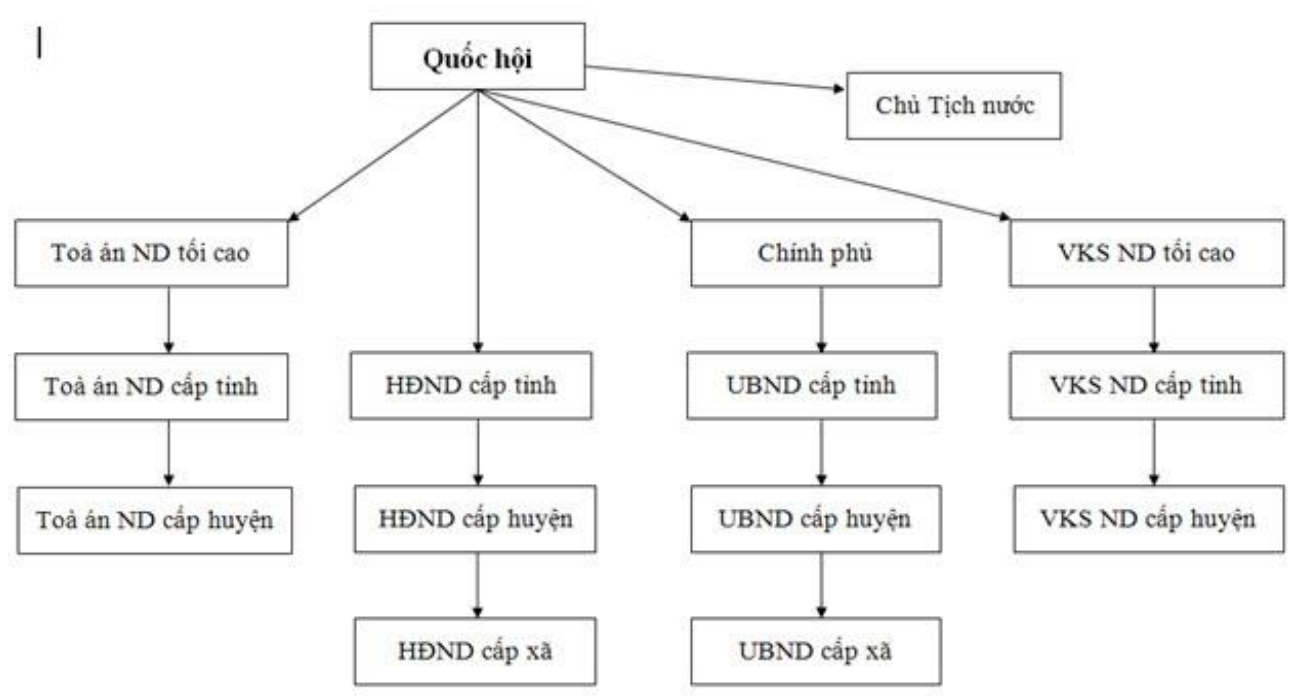

Sơ đồ 3.2. Bộ máy chính quyền Việt Nam.

Tại cấp chính quyền tiểu bang của Hoa Kỳ, mỗi bang có quốc hội bang gồm hai viện (Thượng viện và Hạ viện). Quốc hội bang có quyền sửa đổi và thông qua ngân sách do thống đốc bang đề xuất, và các hạt, thành phố, thị trấn được thành lập bởi chính quyền bang. Chính quyền bang được thành lập trước chính quyền liên bang Hoa Kỳ. Chính quyền liên bang Hoa Kỳ không có quyền can thiệp về một số khía cạnh trong hoạt động của chính quyền bang. Trong khi đó, chính quyền địa phương Việt Nam được thành lập và hoạt động theo sự quản lý của chính quyền trung ương.

Một số đề xuất cho việc đổi mới và hoàn thiện tổ chức bộ máy Nhà nước Việt Nam

Phân cấp quản lý nhà nước là một trong những nội dung của cải cách hành chính và đồi mới tổ chức, hoạt động của bộ máy nhà nước. Cải cách và đổi mới nhằm mục đích có được một bộ máy nhà nước với các cấp chính quyền hoạt động hiệu quả, đáp ứng mục tiêu xây dựng xã hội giàu mạnh, công bằng, dân chủ, văn minh. Cải cách hành chính và đổi mới bộ máy nhà nước phải đảm bảo các nguyên tắc: tất cả quyền lực nhà nước thuộc về nhân dân; bảo đảm sự lãnh đạo của Đảng; tập trung dân chủ và pháp chế. Trong quá trình đổi mới, những ưu điểm và thế mạnh của hệ thống chính quyền các nước phát triển trên thế giới như Hoa Kỳ nên được vận dụng một cách hợp lý để phát huy cao nhất các giá trị đó cho việc hoàn thiện bộ máy Nhà nước Việt Nam. Cải cách hành chính và đổi mới tổ chức, hoạt động của bộ máy nhà nước cần chú trọng những vấn đề sau:

Thư nhất, vận dụng phương thức phân chia quyền lực và cơ chế "kiểm soát - đối trọng" của chính quyền Hoa Kỳ trong việc cải tiến tồ chức, hoạt động bộ máy Nhà nước Việt Nam. Cụ thể như sau: (i) Tiếp tục cải tiến mạnh mẽ về tổ chức và phương thức hoạt động của bộ máy nhà nước theo hướng có sự phân công quyền lực hợp lý, rõ ràng, rành mạch giữa các cơ quan: cơ quan quyền lực, cơ quan hành chính, cơ quan xét xử, cơ quan kiểm sát, giữa Trung ương và địa phương; (ii) Xây dựng cơ chế kiểm soát quyền lực chặt chẽ và hiệu quả giữa các cơ quan quyền lực với nhau.

Thư hai, vận dụng chế độ tự quản địa phương vào tổ chức, hoạt động bộ máy Nhà nước Việt Nam trong bối cảnh Việt Nam đang tiến hành cải cách tổ chức và hoạt động của chính quyền địa phương các cấp trong đó có 
mục tiêu xây dựng chính quyền cơ sở trong sạch, vững mạnh, phát huy quyền làm chủ thực sự của Nhân dân [25]. Trong khuôn khổ thể chế chính trị và Hiến pháp hiện hành của Việt Nam, có thể xem xét tiếp thu một số yếu tố tự quản địa phương cho chính quyền địa phương ở Việt Nam. Nguyên tắc phân định thẩm quyền giữa Trung ương và địa phương bằng luật định, với sự phân định rõ ràng những công việc thuộc thẩm quyền của chính quyền Trung ương, các công việc riêng có của chính quyền địa phương và các công việc hai cấp cùng phối hợp thực hiện là một yếu tố thuộc về chế độ tự quản địa phương có thể áp dụng được ở Việt Nam nhằm gia tăng hiệu quả trong quản lý nhà nước ở Việt Nam [26]. Vận dụng chế độ tự quản địa phương trên các lĩnh vực sau:

(i) Cải tiến việc phân quyền giữa Trung ương và địa phương. Cần tăng cường thêm quyền tự chủ cho địa phương, giảm bớt tối đa sự giám sát hành chính của cấp trên. Đối với những thẩm quyền đã phân quyền cho địa phương - có nghĩa là những thẩm quyền mà địa phương có toàn quyền tự quyết, thì cấp trên không có quyền giám sát: văn bản của chính quyền địa phương chỉ chịu sự kiểm soát duy nhất của pháp luật - mà đại diện là cơ quan tư pháp. Theo kinh nghiệm của Hoa Kỳ, cơ quan có quyền giám sát văn bản của địa phương trong trường hợp này là tòa hành chính - hoặc tòa án tư pháp - ở những nơi không tổ chức tòa hành chính chuyên biệt [27].

(ii) Chính quyền địa phương cần có những thẩm quyền riêng biệt so với các cơ quan nhà nước cấp trên. Đó là các thẩm quyền được thực hiện trong phạm vi phân cấp. Có thể các thẩm quyền này được thừa nhận tại Luật tổ chức, hoặc được quy định rành mạch tại các Luật chuyên ngành. Các thẩm quyền đó có thể được quy định theo hướng liệt kê, hoặc lý tưởng hơn - theo kiểu loại trừ: những gì mà không thuộc phạm vi hoạt động của trung ương thì thuộc thẩm quyền của địa phương [28].

Thứ ba, Xây dựng cơ quan tư pháp độc lập. Trước hết, cần đổi mới tổ chức và hoạt động của cơ quan tư pháp theo nguyên tắc pháp luật là tối thượng. Tòa án chỉ xét xử theo pháp luật, bảo vệ pháp luật, bảo đảm công lý được thực thi. Để đảm bảo hoạt động độc lập cho cơ quan tư pháp, cần học hỏi Hoa Kỳ cơ chế thẩm phán đương nhiệm suốt đời với một mức lương ổn định và không bị cắt giảm bởi bất cứ cơ quan nào. Những sự đảm bảo nói trên nhằm đảm bảo sự độc lập của các thẩm phán trước cơ quan bổ nhiệm chức danh thẩm phán và cơ quan trả lương cho thẩm phán. Nếu thẩm phán thiếu năng lực làm việc hoặc có dấu hiện phạm tội, các ủy ban đặc biệt của Quốc hội có quyển điều tra và xét xử [29].

Thư $t u$, Xây dựng nhà nước pháp quyền. Nhà nước phải điều hành, quản lý bằng pháp luật. Phải tiến hành luật hóa mọi hoạt động của bộ máy nhà nước, loại bỏ sự điều hành, quản lý theo ý chí của người cầm quyền. Mọi cơ quan và cá nhân nhà cầm quyền chỉ được làm những gì mà pháp luật quy định, cho phép [30]. Tất cả những người cầm quyền và người dân đều bình đẳng trước pháp luật.

Thư năm, Xây dựng đội ngũ cán bộ, công chức đủ năng lực, phẩm chất. Để đảm bảo tự do, dân chủ của bộ máy nhà nước và của công dân; hơn nữa, để chọn được người hiền tài cho quốc gia, nâng cao được năng lực nội sinh của bộ máy nhà nước, vấn đề tranh cử tự do vào các chức danh lãnh đạo cao cấp (như Hoa Kỳ) cũng là vấn đề mà Việt Nam cần tham khảo. Cần xây dựng một cơ chế khoa học, tạo điều kiện cho cạnh tranh lành mạnh trong tuyển chọn cán bộ lãnh đạo. Những vấn đề mà Hoa Kỳ đã và đang làm như "đề cao các cơ quan và các chức danh dân cử (chánh án tòa án được nhân dân trực tiếp bầu, thẩm phán được bổ nhiệm với các chế độ đặc thù, viện công tố có tư cách pháp lý độc lập, ...)" thực sự là những điều kiện để cơ quan và cán bộ làm việc theo pháp luật, bảo đảm độc lập, khách quan, trung thực, nâng cao được hiệu lực và hiệu quả của tổ chức và hoạt động bộ máy nhà nước [31].

\section{Tài liệu tham khảo}

[1] Nguyễn Văn Huyên (2007), Hệ thống chính trị Anh, Pháp, Mỹ (mô hình tổ chức và hoạt động), NXB Lý luận chính trị, Hà Nội. 
[2] Dicey, Robert and Albert, Venn. (1950). Law of the Constitution. London: MacMillan.

[3] Michael, Burgess. (2006). Comparative Federalism: Theory and Practice. Routledge.

[4] Taranto, James and Leonardo, Leo. (2004). Presidential leadership: rating the best and the worst in the White House. The Free Press.

[5] Vincent, Bugliosi. (2001). The Betrayal of America: How the Supreme Court Undermined Our Constitution and Chose Our President. Thunder's Mouth Press.

[6] Larry, Gerston. (2007). American Federalism: A Concise Introduction. M.E. Sharpe.

[7] Michael, Burgess. (2006). Comparative Federalism: Theory and Practice. Routledge.

[8] Micheal, Remington. (2002). Federalism and the Constitution: Limits on Congressional Power and Significant Events, 1776 - 2000.

[9] Gerber, Douglas. (1995). To Secure These Rights: The Declaration of Independence and Constitutional Interpretation. New York: New York University Press.

[10] Lenz, Timothy and Holman. (2013). American Government. Mirya.

[11] Nước Mỹ: Hiến pháp Hợp chủng quốc Hoa Kỳ và chú thích, (2004), woldbook.com.

[12] Larry, Gerston. (2007). American Federalism: A Concise Introduction. M.E. Sharpe.

[13] Micheal, Remington. (2002). Federalism and the Constitution: Limits on Congressional Power and Significant Events, 1776 - 2000.

[14] Kincaid John. (2014). Early State History and Constitution. Oxford Handbook of State and Local Government.

[15] Holton, Woody. (2007). Unruly Americans and the Origins of the Constitution. New York: Hill and Wang.

[16] Amar, 1 Reed. (2005). America's Constitution: A Biography. New York: Random House.

[17] Nguyễn Văn Huyên (2007), Hệ thống chính trị Anh, Pháp, Mỹ (mô hình tổ chức và hoạt động), NXB Lý luận chính trị, Hà Nội.

[18] Vũ Dương Huân, (2002), Hệ thống chính trị Mỹ cơ cấu và tác động đối với quá trình hoạch định chính sách đối ngoại, NXB Chính trị Quốc Gia, Hà Nội.

[19] Nguyễn Cửu Việt, (2005), Phân cấp quản lý trong mối quan hệ giữa trung ương và địa phương, Tạp chí Nghiên cứu lập pháp, số 7 .
[20] Hiến pháp mới 2013 hiến định xây dưng, hoàn thiện nhà nước pháp quyền xã hội chủ nghĩa Việt Nam,

<http://www.molisa.gov.vn/vi/Pages/chitiettin.asp $x$ ?IDNews $=22248>$, truy cập ngày 20/10/2017

[21] Luật tổ chức Quốc hội nước Cộng hòa xã hội chủ nghĩa Việt Nam, <http://www.moj.gov.vn/vbpq/lists/vn\%20bn\%20 php\%20lut/view_detail.aspx?itemid=29972>, truy cập ngày 20/09/2017.

[22] Luật tổ chức Chính phủ nước Cộng hòa xã hội chủ nghĩa Việt Nam, <http://moj.gov.vn/vbpq/lists/vn\%20bn\%20php\% 20lut/view_detail.aspx?itemid=30512>, truy cập ngày 20/09/2017.

[23] Luật tổ chức Tòa án nhân dân tối cao nước Cộng hòa xã hội chủ nghĩa Việt Nam, <http://www.moj.gov.vn/vbpq/lists/vn\%20bn\%20 php\%20lut/view_detail.aspx?itemid=29971>, truy cập ngày 20/09/2017.

[24] Luật tổ chức Viện Kiểm sát nhân dân tối cao nước Cộng hòa xã hội chủ nghĩa Việt Nam <http://www.moj.gov.vn/vbpq/lists/vn\%20bn\%20 php\%20lut/view_detail.aspx?itemid=22414>, truy cập ngày 20/09/2017.

[25] Trần Thị Minh Châu, (2009), Chế độ tự quản địa phương của một số nước trên thế giới, Tạp chí Tổ chức nhà nước, số 4.

[26] Nguyễn Văn Cương, Kinh nghiệm quốc tế về tự quản địa phương và một số gợi ý về việc tiếp tục hoàn thiện cơ chế quản trị địa phương cho Việt Nam,

<http://khpl.moj.gov.vn/qt/tintuc/Pages/nghiencuu-trao-doi.aspx?ItemID $=31>$, truy cập ngày 21/09/2107.

[27] Nguyễn Hoàng Anh, (2014), Chính quyền địa phương tự quản trong pháp luật một số quốc gia, Tạp chí Tổ chức nhà nước, số 10 .

[28] Nguyễn Hoàng Anh, (2014), Chính quyền địa phương tự quản trong pháp luật một số quốc gia, Tạp chí Tổ chức nhà nước, số 10 .

[29] Nguyễn Văn Huyên (2007), Hệ thống chính trị Anh, Pháp, Mỹ (mô hình tổ chức và hoạt động), NXB Lý luận chính trị, Hà Nội.

[30] Nguyễn Văn Huyên $(\mathrm{Cb})$, Hệ thống chính trị Anh, Pháp, Mỹ (mô hình tố chức và hoạt động), NXB Lý luận chính trị, Hà Nội, 2007.

Nguyễn Văn Huyên (2007), Hệ thống chính trị Anh, Pháp, Mỹ (mô hình tổ chức và hoạt động), NXB Lý luận chính trị, Hà Nội. 


\title{
Model of the State Governments in the United States and Suggestions for Decentralization of State Organizations in Vietnam
}

\author{
Pham Quang Huy ${ }^{1}$, Pham Ngoc Lam Giang ${ }^{2}$ \\ ${ }^{1}$ Department of Legal Affairs, the Ministry of Finance \\ ${ }^{2}$ Vietnam Institute of American Studies, Vietnam Academy of Social Sciences
}

\begin{abstract}
The paper analyzes the connection between the Federal Government and State governments in the United States, decentralization and autonomy of the State governments. The paper concludes with recommendations for decentralization of state organizations in Vietnam.

Keywords: State organ, U.S Federal government, U.S State government
\end{abstract}

